\title{
JAZZKULTTUURIN MURROS JA MAAILMANKUVAN MUUTOS POPULAARIMUSIIKISSA
}

Viron musiikin symposiumissa tämän vuoden maaliskuussa keskusteltaessa kansallisuudesta ja kansainvälisyydestä musiikissa kävi ilmi, että kansojemme musiikin muutoksen yhteinen ulkoinen vaikuttaja on ollut kaksinapainen akseli, jonka itäisessä päässä on Saksa, toisessa päässä Siperia. Itäistä alkuperää oleva arktinen shamaanimusiikki, "avoin muoto", alati virtaava ja päättymätön olotila, on väistynyt länsimaisen musiikin suljettujen muotojen, tonaalisuuden ja funktionaalisen harmonian kahlitseman ajattelun tieltä. Musiikillisten käsitysten muutosten taustalla on perusteellinen muutos koko kulttuurin rakenteessa, muutos pyyntikulttuurista kaski- ja maanviljelykulttuurin kautta eurooppalaiseksi kaupunkikulttuuriksi.

Musiikin muutoksen keskeisin piirre on ollut musiikin tehtävän erikoistuminen: muinaissuomalainen musiikki oli yleistä ja yhtäläistä, se oli samalla sekä maagis-uskonnollista, ritualistista että esteettistä, samalla kertaa tiedettä, taidetta, uskontoa ja yhteisölllisyyttä. Länsimaistumisen myötä alkoi erikoistuminen: maagis-ritualistinen alue siirtyi vähitellen kristillisen kirkkomusiikin piiriin, talonpoikaiskulttuuri kehitti omat kyläyhteisöön liittyvät läntisperäiset seremoniansa, ja lopulta,

*) Lectio praecursoria Helsingin yliopiston pienessä juhlasalissa 8.4.1989 
1800-luvun aikana, eurooppalainen kaupunkikulttuuri loi omat musiikilliset käytäntönsä, populaarimusiikin. Uuden kaupunkifolkloren tärkeimpiä lajeja ovat kylpylöissä, ravintoloissa, seurapiiritilaisuuksissa ja myöhemmin elokuvateattereissa esitetty salonkimusiikki, aluksi sotaväen ja myöhemmin erilaisten järjestöjen ja yhdistysten torvisoitto, kansanomainen musiikkiteatteri operetista kabaree-, revyy- ja kuplettimusiikkiin, sirkusmusiikki ja lopulta italialaisten posetiivareiden ja haitarinsoittajien esittämä katumusiikki. Populaarimusiikin synty ja käytännöt olivat paljolti yhteydessä maamme taidemusiikin organisoitumiseen, orkesteri-, konsertti- ja oopperalaitokseen, kansanvalistusajattelun vaalimaan kuoro- ja soittokuntatoimintaan, musiikkikoulutukseen, nuotti-, ja soitinkauppaan ja kansainvälisiin kontakteihin musiikkijärjestelmien sisällä. Sekä taide- että populaarimusiikki oli saksalais-venäläisen romantiikan joko suoraa tai sovellettua lainaa. Siitä kuului sääty-yhteiskunnalle ominainen ihannoiva idylli, ristiriitoja karttava biedermayer. Tästä on hyvä esimerkki salonkimusiikki, 1800-luvun yleisin populaarimusiikin muoto.

Suomalainen salonkimusiikki alkoi kreivi Heydenin salonkiorkesterista Suomenlinnasta, kehittyi ja yleistyi Ullanlinnan kylpylässä, joka oli tuolloin Pietarin hienoston idyllinen ja "pikkukaupunkimainen" kesänviettopaikka, ja yleistyi vähitellen kasvavan pääkaupungin muissakin huvikäytännöissä.

Esteettisessä mielessä salonkimusiikki oli kaavamaista ja harmitonta. Vaikka sen materiaali oli peräisin klassis-romanttisesta taidemusiikista, huvielämän käytännöt olivat puristaneet siitä ytimen ulos ja jättäneet jäljelle vain kuoren. Tietoisen kaavoittumisen seurauksena salonkimusiikissa kuului laskelmoitu ja alati toistuva hilpeän ja sentimentaalisen aineksen vastakkaisuus, duurin ja mollin, nopean ja hitaan väsyttävyyteen asti toistettu musiikillinen viehe, jota tilapäisesti yritettiin uudistaa soittimellisen virtuoottisuuden lumolla. Salonkimusiikki oli hedonistista idyllin sallimissa rajoissa. Se varjeli tiukasti itsensä talonpoikaismusiikin karkeuksilta, mutta torjui myös taidemusiikin taiteeksi tekevät kaavamaisuutta rikkaammat esteettiset ja intellektuaaliset tekijät, siitä huolimatta, että mielellään käytti itsestään "konserttimusiikin" arvovaltaista nimikettä.

Salonkimusiikilla oli monia sukulaisia. Torvisoitto oli sen kansanomaisempi muunnos, ja täysin yhtäläinen sekä materiaalin, tekstuurin että vastaavien musiikillisten tekniikkojen suhteen, vain tanssisoitossa saattoi tuntua idylliä rikkovaa karkeutta. Kansallisen heräämisen myötä 
synnytetyt uudet musiikki-instituutiot, etenkin kansallispukuun puettu kuoroliike laulujuhlineen nojasi useimmiten vastaavaan saksalais-romanttiseen ihannoivaan ja kaavamaiseen ajatteluun. Syyt olivat sekä ideologisia että kaupallisia: idyllin avulla pyrittiin luomaan kansallista, särötöntä yhtenäisyyttä, jota säätyläistö piti ohjaksissaan, ja samalla liikkeen käyttöön liittyvästä nuottituotannosta ja -kaupasta oli tullut uusi kaupunkikulttuurille ominainen liiketoimi. 1800-luvulla saksalaisen romantiikan hallitsema eurooppalainen musiikkikäsitys oli siten pääkaupunkiseudulla jo juurtunut lopullisen ja pysyvän tuntuiseksi olotilaksi: niinpä esimerkiksi kaupunkikulttuuriin tuolloin liittynyt paaria-ilmiö, katusoitto, oli karkeudestaan ja kerjäläisluonteestaan huolimatta harmitonta klassis-romanttista säätyläismusiikkia: posetiivareiden suosikkisäveltäjä oli Giuseppe Verdi, ja haitarinsoittajien musiikillisiin käsityksiin sisältyi kuin luonnostaan funktionaalinen sointukäsitys - tämä sointujärjestelmä, jonka ekspressiivisin huipentuma oli vähennetty septimisointu, "dimi", oli näet haitarin sisään rakennettu periaate.

Afroamerikkalaisen musiikin ensimmäiset virtaukset eivät mitenkään rikkoneet vakiintunutta idylliä: 1800-luvun loppuvuosina Ylioppilastalolla ja Palokunnantalolla kuultu neekerimusiikki, negro spirituaalit, soveltuivat ongelmatta ajan muihin folkloristisiin ilmiöihin, mustalais-wieniläis-tirolilais-italialais-espanjalaisen estradimusiikin sekaan. Saksofoni oli vielä toistaiseksi sotilassoittokuntien, mm. kuuluisan Apostolin soittokunnan uutuussoitin, ja amerikkalaisilla ragtime-, oneja twostepp-kappaleilla ja tangoilla oli vain muotitanssin rekvisiitan merkitys - mm. cakewalkia, "alkuperäisen koomista neekeri-, intiaani- ja cowboytanssia", kuultiin ensimmäisen kerran 1905 Cinisellin sirkuksessa koko henkilökunnan voimin esitettynä. Vasta jazzin läpimurto rikkoi idyllin.

Jazzin aiheuttamalle hämmennykselle on runsaasti syitä itse musiikissa: uusi rytmi, sointi ja tulkintakäsitys oli vieras ja usein vastenmielinen eurooppalais-kansallisen perinteen sisäistäneelle "konserttimuusikolle": hän vierasti jazzin improvisointiperiaatetta, "muuttamista", "omasta päästä soittamista", karsasti jazzin "epäpuhtaita" mikrointervalleja, glissandoja ja tremoloja, "simpanssien lemmenkurahteluja", jazzin raakaa ja sivistymätöntä affektia. Taustalla on kuitenkin kaupunkikulttuurin muutokseen liittyviä tekijöitä; voimakkaan ja pitkäikäiseksi osoittautuneen ristiriidan voikin nähdä keskieurooppalaisen idealistisen säätyläiskulttuurin ja angloamerikkalaisen utilitaristisen kaupunkikulttuurin yhteentörmäyksenä. 
Pelottavin piirre jazzissa oli säätyläismusiikin kannalta amerikkalaisen muotimusiikin uusi, häikäilemätön pragmatismi, sekä taloudelliseen hyötyyn perustuva jenkkikulttuurin kaupallisuus, "säilyketölkkiideologia", että peittelemätön hedonistinen ja karnevalistinen piirre. Karnevalismi oli täysin sopimaton esimerkiksi salonkimusiikin tekopyhään idylliin, karnevalismin kirot oli kuin korsettia kiristämällä kätketty silkki- ja Picknick-tanssiaisten ja Allegri-iltamien karamellikaapuun. Sen sijaan talonpoikaismusiikille ja joillekin kaupungin kansanomaisimmille musiikkimuodoille, mm. kupletille, karnevalismin ajatus ei ollut vieras: esimerkiksi kuplettilaulaja Iivari Kainulainen, "Kilu-Kalle", saattoi laulaa estottomasti levylle oman parodiavirtensä:

\section{Jo joutui armas aika ja suvi suloinen, nyt ilmassa on taika ja veitsi verinen}

Suomalaisen jazzin akkulturaatiotyypeistä, keskieurooppalaisesta salonkijazzista, angloamerikkalaisesta hot-jazzista ja kotimaisesta haitarijazzista ainoastaan viimemainittu osasi yhdistää toisiinsa sekä agraarin talonpoikaisen sekä urbaanin angloamerikkalaisen karnevalismin. Juuri tämä seikka teki siitä muita suositumman ja kilpailijoihinsa nähden ylivoimaisen. Tämä Dallapé-orkesterin piirissä syntynyt tanssimusiikkityyli, kansanmusiikin kaupungistunut jatke, on oiva esimerkki eri kulttuurien, perinnekerrostumien ja musiikillisten käsitysten sekoittumisesta, valikoitumisesta ja uudelleentulkinnasta 1920-luvun pääkaupunkiseudun erikoisoloissa. Haitarijazzilla oli huomattavan voimakas agraaritausta. Tyylin luonut ja ylläpitänyt, Helsingin esikaupunkialueilla asunut työläisnuoriso eli vielä kansalaissodan jälkeen sangen maalaismaisissa oloissa: Pitäjänmäellä, Käpylässä, Pasilassa, Herttoniemessa, Leppävaarassa jne. pidettiin vielä tuolloin pihoilla sikoja, vuohia ja hevosia ja viljeltiin perunaa. Lavoilla ja silloilla käytiin joukolla tansseissa potkukelkoilla tai jalkapatikassa. Eri kaupunginosien väliset "kylätappelut" olivat yleisiä. Urbaanin ja agraarin, kotimaisen ja afroamerikkalaisen populaarimusiikin sattumanvarainen sulautuminen ja säätyläiskulttuuria torjuva, jopa parodioiva luonne tulee oivallisesti esiin Dallapé-orkesterin alkuvaiheisiin liittyvillä Kivinokan retkillä: sinne mentiin Hakaniemestä kilpaa kahdella kirkkoveneellä päämääränä profaanit toiminnat. Tukikohtia olivat omatekoiset havumajat, parakit ja tanssilava, liturgioina vilkaistiin työväenjärjestöjen lehdet ja laulukirjat, urkujen tilalla pauhasi Dallapé-merkkinen haitari ja kirkonkellojen sijaan kumah- 
teli orkesterin uusi rumpu, merestä ongittu pirtukanisteri. Musiikin alueella nokkela karnevalismi ulottui kuitenkin vain pintatasoon, itse musiikissa ei saksalais-venäläisillä, tsaristis-keisarillisilla intonaatioilla ollut vielä hätäpäivää.

Jazzinkin aikakaudella Siperian-Saksan akseli oli kaikesta huolimatta kääntynyt lopullisesti Saksan suuntaan. Olisiko sittenkin Alaskan, Pohjolan, Petsamon, Uralin ja Altain öiden huumassa kuultavissa shamaanirummun etäinen jytke? Vai onko kyseessä vain yleisinhimillinen, niin jazzille kuin tangolle, polkalle, valssin kahdelle ensimmäiselle iskulle, samballe, rumballe tai diskotanssille ominainen kiihtyneen ja kiihoittuneen sydämen syke:

Kaulaltas pölyä puuterin

hengitän suin ja sieraimin.

Kuuletko, kuin tän' yönä soi

Alaska, Bombay ja Billy Boy? 